\title{
Corrigendum: An Attempt to Estimate the Impact of the Spread of Economic Flows on Latenian Urbanization
}

\author{
Clara Filet * \\ UMR 8546 'AOROC, Celtes et Etrusques', UMR 7041 'ArScAn, Archéologies Environnementales', EA 4543 'SAMM', \\ University Paris 1, Paris, France
}

Keywords: spatial interactions, modeling, La Tène, urbanization, trade

\section{A Corrigendum on}

An Attempt to Estimate the Impact of the Spread of Economic Flows on Latenian Urbanization by Filet, C. (2017). Front. Digit. Humanit. 3:10. doi: 10.3389/fdigh.2016.00010

In the original article, there was a mistake in Figure 2 as published. In the map, there was an error in the labels for n.1 "Meulan" and n.2 "Nanterre." The corrected Figure 2 appears below.

Additionally, there was an error in the text of the original published article. The status of the city of Orléans during La Tène times was unclear.

A correction has been made to the section Using Rihll and Wilson Model for This Case Study,

Edited and reviewed by:

Francesca Fulminante,

University of Bristol, United Kingdom

${ }^{*}$ Correspondence:

Clara Filet

clara.filet@gmail.com

Specialty section:

This article was submitted to

Digital Archaeology,

a section of the journal

Frontiers in Digital Humanities

Received: 14 January 2019

Accepted: 01 February 2019

Published: 22 February 2019

Citation:

Filet C (2019) Corrigendum: An Attempt to Estimate the Impact of the

Spread of Economic Flows on Latenian Urbanization.

Front. Digit. Humanit. 6:2. doi: 10.3389/fdigh.2019.00002

"As the cost ratio particularly benefits to river paths, it is not surprising that the major flows follow the main rivers. From the 67 input sites, a dozen settlements are particularly underlined by the model. In the Parisian Basin, Meulan, Nanterre, and several other open agglomerations in the surroundings (Bobigny and Epiais-Rhu) seem significantly favored by downstream flows from several confluences (Seine, Oise, Marne). Orléans stands out as remarkable in the Loire Basin. Orléans stands out as remarkable in the Loire Basin. This statement is consistent with both archeological and historical knowledge, which place it as a major economic center of Carnute people ${ }^{7}$. The picture well emphasizes that this prominent status can notably be explained by the role of this city as an intermediary node to travel from the Loire basin to northern areas and the Eure and Seine Rivers. Varennes-sur-Allier and Roanne seem to benefit from the same position as crossroads between terrestrial and fluvial paths on the Allier River on the one hand and upstream Loire River on the other. Finally, Mâcon, Chalon-sur-Saône, and Verdun-sur-le-Doubs are highlighted as the three main nodes of the Saône and Rhône Basin. If Mâcon is still not well known by archeologists, the two others are already pointed out as essential economic hubs on the Saone River by the literature (Billoin et al., 2009; Barral and Lallemand, 2014). Tens of thousands of Roman amphorae were discovered in the River near Chalon-sur-Saône (see Feugnet, 2018).”

The authors apologize for these errors and state that they do not change the scientific conclusions of the article in any way. The original article has been updated. 


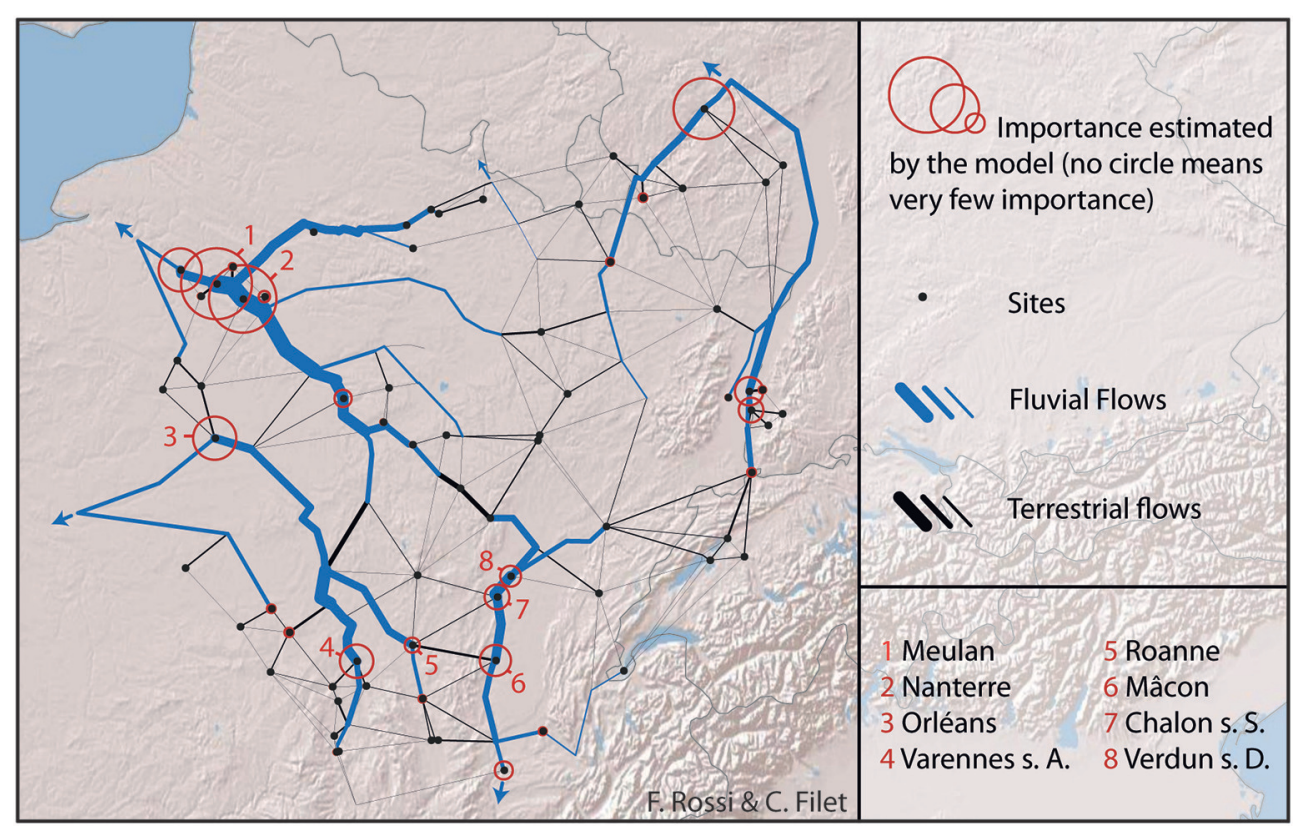

FIGURE 2 | Exemplary output for settlements of more than 7 ha and dated from LT D1. Created by author (Basemap: Copyright $\odot 2017$ Esri. All rights reserved).

\section{REFERENCES}

Barral, P., and Lallemand, D. (2014). Les agglomérations ouvertes du IIe siècle av. J.-C. à spécialisation artisanale et commerciale: deux exemples du Centre-Est de la France, Varennes-sur-Allier (Allier) et Verdun-sur-le-Doubs (Sâone-et-Loire). In Produktion - Distribution - Ökonomie, Siedlungs- und Wirtschaftsmuster der Latènezeit, Akten des internationalen Kolloquiums in Otzenhausen, 28.-30. Oktober 2011, Edited by S. Hornung, 205-230. Bonn: Verlag Dr. Rudolf Habelt GmbH.

Billoin, D., Bonnamour, L., Mouton, S., and Videau, G. (2009). L'agglomeration de Chalon-sur-Saône de La Tène finale au début de la période gallo-romaine: un port comptoir aux origines de Cabilonnum. In Lâge du Fer dans la boucle de la Loire. Les Gaulois sont dans la ville, Vol. 2008, Edited by O. Buchsenschutz, M.-B. Chardenoux, S. Krausz, and I. Ralston (dir.), 263-278. Bourges: Actes du colloque de l'AFEAF.

Feugnet, A. (2018). Le Choix, très Sélectif, des Importations Grecques et Romaines Dans les Sociétés Celtiques (250-25 av. n. è.). Paris: Paris 1 Panthéon-Sorbonne.

Copyright (c) 2019 Filet. This is an open-access article distributed under the terms of the Creative Commons Attribution License (CC BY). The use, distribution or reproduction in other forums is permitted, provided the original author(s) and the copyright owner(s) are credited and that the original publication in this journal is cited, in accordance with accepted academic practice. No use, distribution or reproduction is permitted which does not comply with these terms. 